\title{
ふく射機能性表面の放射シミュレーション*
}

平島 大輔 $* 1$, 花村 克悟 $* 2$

\section{Simulation for Thermal Radiation Emitted from Functional Surface}

\author{
Daisuke HIRASHIMA*1 and Katsunori HANAMURA \\ ${ }^{* 1}$ Department of Mechanical and Control Engineering, Tokyo Institute of Technology \\ 2-12-1, Ookayama, Meguro-ku, Tokyo, 152-8552, Japan
}

\begin{abstract}
Radiative characteristics of one-dimensional structured emitter was investigated through calculating emission of thermal radiation by solving the Maxwell's Equations using a FDTD method. The radiative simulation based on fluctuational electrodynamics enable to evaluate quantitative emission of thermal radiation. For a specular emitter made of nickel metal with a thin-transparent film, some interference was described through simulation solving emission of thermal radiation. For a shallow-grooved surface emitter made of silicon carbide, surface-phonon polaritons were coupled with a propagating-radiation by the periodic structure. Finally, the characteristics of emission controls by the specular metal with the thin-transparent film and the shallow-grooved surface emitter were illustrated and compared from a point of view of emission of thermal radiation.
\end{abstract}

Key Words : Thermal Radiation, Spectral Control, Numerical Simulation, FDTD Method

1.は じめ に

熱光起電力 (Thermophotovoltaic: TPV) 発電は熱エネルギーを，電磁波を介して，電力に変換する手法として 注目されている.TPV 発電では, 加熱された物体あるいは火炎から放射された熱うく射が, 光起電力効果を有す る化合物半導体電池 (TPV セル) により電力へ変換される.この TPV セルは, 近赤外域の熱ふく射を電力八変換 するため, GaSb などの比較的バンドギャップの小さい材料 (感度波長 $0.8-1.8 \mu \mathrm{m}$ ) で構成され，特定の波長域で のみ光を電力へ変換することができる .このため TPV 発電の高効率化には熱うく射の放射スペクトルを発電可能 な゙波長域に集約することが必要である．

放射スペクトルを制御する手法として，所望のスペクトルを有する化学種を用いる方法と金属表面に微細構造 を施す方法が知られている ${ }^{(1)}$. 化学種を調整する方法では , 近赤外域の特定の波長に放射ピークを有する希土類元 素を用いる方法が検討されている．たとえば $\mathrm{Er}$ 元素をドープさせたセラミックスでは $1.3-1.7 \mu \mathrm{m}$ など，特定の 波長域で放射率が高い值をとるものの, 光の帯域が狭いため輸送される光エネルギー量を大きくすることが難し い.一方，金属材料表面に微細構造を構築する手法は，表面形状によって電場の境界条件を課し，物体表面の電 磁場を制御することによって必要な放射スペクトルを得るものである．この手法は，表面形状のパラメタを調整 することによって比較的柔軟に放射スペクトルを制御できるという利点がある．

金属表面に微細構造を施すことによる放射スペクトルの制御は，表面において波長オーダーで屈折率を変化さ せ, 物体表面の電磁場を制御することである.この微細構造は, 屈折率変化の与え方によって 1 次元構造, 2 次 元構造， 3 次元構造に分けられる.

1 次元構造として，金属表面に透明薄膜を積層させる方法と回折格子状の構造を施す方法か検討されている．金 属表面に透明薄膜を積層させる方法 (薄膜系) は, 放射した熱うく射を, 透明薄膜を用いて, 干渉させることに

* 原稿受付 2011 年 5 月 20 日

*1 学生員, 東京工業大学大学院理工学研究科機械制御システム専攻 （干152-8552 東京都目黒区大岡山 2-12-1）

*2 正員, フェロー, 東京工業大学大学院理工学研究科機械制御システム専攻 （干152-8552 東京都目黒区大岡山 2-12-1）

E-mail: hanamura@mech.titech.ac.jp 
よって放射率を増加させたり減少させたりすることができる ${ }^{(2)}$.一方，回折格子状の構造を用いる方法 (格子系) では，金属表面に，放射する電磁波の波長に比べて非常に小さい溝を製作することで，金属と空気という周期的 な屈折率変化を与える . 溝に平行な磁場をもつ $\mathrm{p}$ 偏光の電磁波成分において金属表面に誘起される表面波は , 周 期構造により周期的な電磁場を空気中に誘起する．このとき，誘起された電磁場が空気中を伝播する電磁波とな りうる場合，この表面波の一部は散乱光となり遠方へ放射される ${ }^{(3)(4)(5)}$.

2 次元構造として，金属表面に空洞を製作することによって放射特性を制御する方法が検討されている ${ }^{(6)}$. 空 洞を施し空洞内部の電磁場を共鳴させることによって, 空洞の開口部において, 開口径以下の波長域の電磁場が 平滑面に比へて増強される.この 2 次元構造では, 開口径の 2 倍となる波長まわりの比較的広い波長域で放射率 が増加し，開口径に比べて十分に長い波長域での放射率が平滑面の兰れと同程度であることが示されている．ま た，3 次元構造として，3 次元フォトニック結晶を用いる方法が検討されている(7). この方法では, 放射体内部の 電磁場モードを制御することによって放射特性が制御される .このときフォトニックバンドギャップによって長波 長域で放射を抑制する一方で，短波長域で高い放射率を得られることが示されている．

ここで1 次元格子系では，表面波の波数ベクトルと構造の周期から導かれる，散乱光の放射角度で放射率か増 加する . また 2 次元構造では, 空洞が完全導体で構成されると仮定したときの空洞共振波長が放射率の最大値を与 える波長と一致する .さらに3 次元構造では，フォトニックバンドギャップに対応する波長帯が放射率の高い波長 域に対応する．このように特徵的な挙動をする条件 (点) と形状との対応が明確である一方で，波長特性や指向 性などの広い領域にわたる特性を求めることは容易でない，关こで数值シミュレーションを用いて，電磁波の反 射あるいは放射を解くことで放射特性が検討される．反射計算では，指向性入射半球反射率を求めることで指向 性放射率が算出される．反射計算として現在広く用いられている手法が厳密結合波解析 (Rigorous Coupled-Wave Analysis; RCWA) である.RCWA は回折格子の回折効率を求める手法として開発されたものである . RCWA では， 解かれる電磁波モ一ドを入射波と高次回折光に限定して電磁波解析が行われる．この手法は計算の過程でいくつ かの仮定が含まれているため, 手法をふまえて適用範囲を検討する必要があるといえる．一方，マックスウェル 方程式を解いて放射を求める場合，計算領域周囲の境界条件として無反射の境界条件か課されればよい，課され るべき境界条件は単純であるが, 放射がモデル化される必要があること, 計算負荷が反射計算に比べて大きいこ となど利点のみとはいえない，しかし RCWAのように計算過程で仮定が含まれていないため，解析対象を選ばな いといえる．また，ふく射輸送を考える系が十分離れている場合，放射体単体の放射特性を求めればよいが，物 体間距離が波長以下になると，ふく射輸送は近接場効果を含むため放射を直接解く必要がある.

本研究では, 物体の放射特性を求める手法として放射を直接解く方法を用い, 1 次元構造の薄膜系・格子系の 放射特性を評価することを目的としている．この1次元構造は，干渉による放射率の制御あるいは周期構造との 相互作用といった，放射制御技術の基礎をなす系である．本論文ではまず放射を解く方法について，現在放射モ デルとして用いられている摇動電磁気学を概説し, 弚の理論体系を用いて放射を数值的に解く方法について述べ る.放射現象では電磁波か球面状に伝播するため，原理的には 3 次元計算を要する．一方，1 次元構造の放射特 性について，定性的にではあるが，2次元領域での計算によって精度よく求められることが示されている.最後 に，熱うく射の放射という観点から，薄膜系と格子系について放射制御手法の相違を考察する．

記号表

E electric field, $\mathrm{V} / \mathrm{m}$

$G^{E, H} \quad$ electric/magnetic dyadic Green's function, $\mathrm{m}^{-1}$

H magnetic field, $\mathrm{A} / \mathrm{m}$

$i, j \quad$ grid point in Cartesien coordinate for FDTD simulation

$\mathbf{J}^{s} \quad$ fluctuating current vector, $\mathrm{A} / \mathrm{m}^{-2}$

$k \quad$ wavevector, $\mathrm{m}^{-1}$

$\mathbf{r}$ position vector of observation point, $\mathrm{m}$

$\mathbf{r}_{s} \quad$ position vector of radiation source, $\mathrm{m}$

S Poynting vector, $\mathrm{W} / \mathrm{m}^{2}$ 


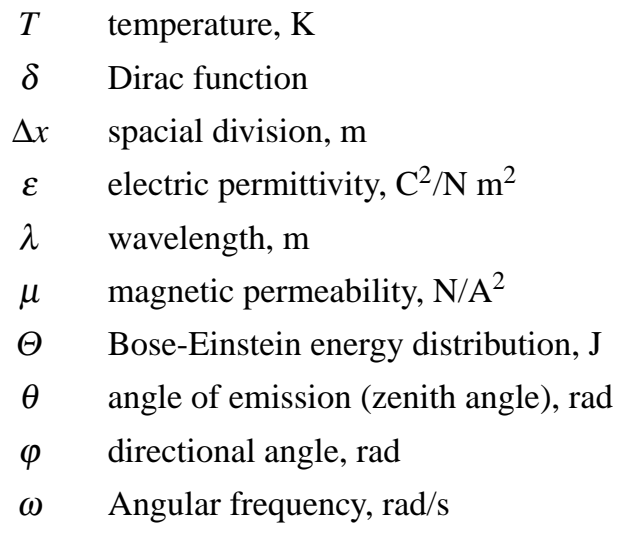

Subscripts / Superscripts

$\begin{array}{cl}0 & \text { vacuum } \\ * & \text { complex conjugate } \\ D & \text { dielectric } \\ F & \text { metal with a thin film } \\ G & \text { grating structure } \\ M & \text { metal } \\ N & \text { normal direction } \\ r e f & \text { reference } \\ s, p & \text { polarization state } \\ s p e c & \text { specular surface } \\ \| & \text { parallel to surface }\end{array}$

2. 放射シミュレーション

\section{$2 \cdot 1$ 摇動電磁気学}

物体からのふく射の放射を定量的に評価する理論体系として摇動電磁気学が知られている．本節ではまず产の 摇動電磁気学を用い, 放射特性を数值計算で求める手法について言及する.

有限温度をもつ物体内部において熱摇動する格子振動により電磁波が生じる．弚の電磁波は，物体内部を伝播 し境界面を透過したのち，開放空間へ放射される．このような電磁波の発生，伝播，境界面現象という一連の過 程はマックスウェル方程式に従う. 摇動電磁気学では, この熱摇動は周波数, 空間, 方向に関して完全にランダム なものとしてモデル化される .このとき熱摇動する格子振動の寄与は摇動電流としてマックスウェル方程式の電 流密度項に導入される .ここで物体内部のある点 $\mathbf{r}_{s}$ の摇動電流が空間のある観測点 $\mathbf{r}$ に作る電磁場は, マックス ウェル方程式の解であるグリーン関数 $\overleftrightarrow{G}$ と摇動電流の積で表現される.いま放射体の体積 $V$ 全体から熱ふく射が 放射されることを考えると，観測点 $\mathbf{r}$ に生じる電磁場は，各摇動電流の寄与の積分値として次のように表される。

$$
\begin{aligned}
& \mathbf{E}(\omega, \mathbf{r})=i \omega \mu_{0} \int_{V} \overleftrightarrow{G^{E}}\left(\omega, \mathbf{r}, \mathbf{r}_{s}\right) \mathbf{J}^{s}\left(\omega, \mathbf{r}_{s}\right) \mathrm{d} \mathbf{r}_{s}^{3}, \\
& \mathbf{H}(\omega, \mathbf{r})=\int_{V} \overleftrightarrow{G^{H}}\left(\omega, \mathbf{r}, \mathbf{r}_{s}\right) \mathbf{J}^{s}\left(\omega, \mathbf{r}_{s}\right) \mathrm{d} \mathbf{r}_{s}^{3} .
\end{aligned}
$$

ここで式中のグリーン関数は $3 \times 3$ の行列である . 图 1 は式 (1), (2) の概念を表す . この図は, 物体内部全体から 電磁波が発生し, 弚れらが観測点に電磁場を誘起させることを示す. 各摇動電流ベクトルと光れ攵れが作る電磁 場ベクトルの量的関係はグリーン関数で定義される .

ここでわれわれが観測する值 (エネルギー) はポインティングベクトルの時間平均值であり，光の評価にはラン ダムな摇動電流の統計的な平均值が用いられる. Rytov は物体内部の熱摇動の統計平均 (アンサンブル平均) とし 


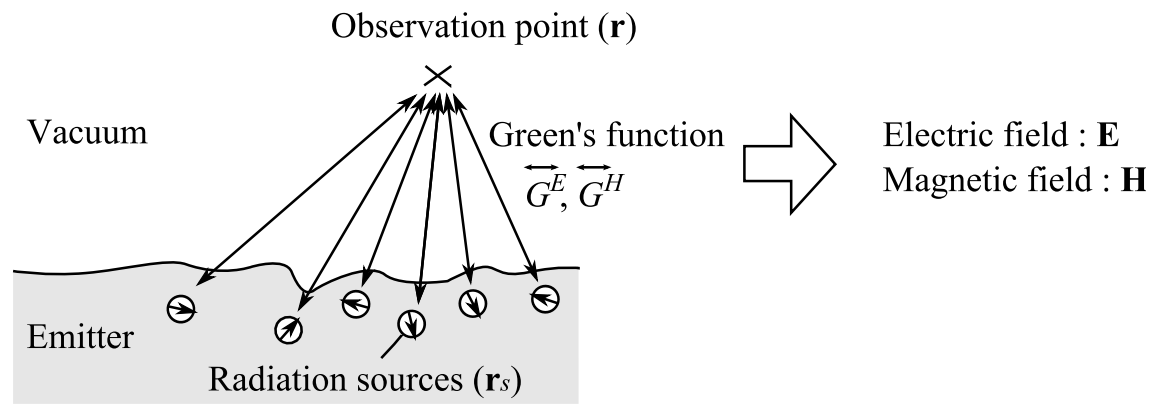

Fig. 1 Schematic image of Eqs. (1), and (2).

て以下の式を提案した ${ }^{(8)}$.

$$
\left\langle J_{\beta}^{s *}\left(\omega^{\prime}, \mathbf{r}^{\prime}\right) J_{\alpha}^{s}(\omega, \mathbf{r})\right\rangle=\frac{\varepsilon_{0} \varepsilon^{\prime \prime}(\omega) \omega}{\pi} \Theta(\omega, T) \delta\left(\mathbf{r}-\mathbf{r}^{\prime}\right) \delta_{\omega \omega^{\prime}} \delta_{\alpha \beta} .
$$

式中，電流密度の下付き $\alpha, \beta$ は直交座標系の方向成分を示す . ここで熱摇動のアンサンブル平均には, 物体温度 の寄与がボーズ・アインシュタインのエネルギー分布関数 $\Theta(\omega, T)=\hbar \omega /\left(\exp \left[\hbar \omega / k_{B} T\right]-1\right)$ として, 誘電率を局

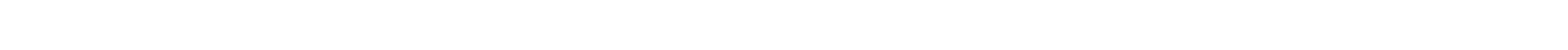
として導入されている．

式 (1) と式 (2)の積をとり，式 (3) を代入すると電場と磁場の相関関数が求められる ${ }^{(9)}$ (付録 $\mathrm{A}$ 参照)．電磁場 の相関関数を用いると，観測点 $\mathbf{r}$ におけるポインティングベクトルの時間平均值は

$$
\langle\mathbf{S}(\omega, \mathbf{r})\rangle=2 \frac{\varepsilon_{0} \omega}{\pi} \varepsilon_{r}^{\prime \prime}(\omega) \Theta(\omega, T) \operatorname{Re}\left\{i \mu_{0} \omega \int_{V}\left[\begin{array}{l}
G_{z l}^{H *} G_{y l}^{E}-G_{y m}^{H *} G_{z m}^{E} \\
G_{x l}^{H *} G_{z l}^{E}-G_{z m}^{H *} G_{x m}^{E} \\
G_{y l}^{H *} G_{x l}^{E}-G_{x m}^{H *} G_{y m}^{E}
\end{array}\right] \mathrm{d} \mathbf{r}_{s}^{3}\right\}
$$

のように求められる .ここで被積分関数はグリーン関数の積に関する総和 $G_{\beta x}^{H *} G_{\alpha x}^{E}+G_{\beta y}^{H *} G_{\alpha y}^{E}+G_{\beta z}^{H *} G_{\alpha z}^{E}=G_{\beta l}^{H *} G_{\alpha l}^{E}$ として与えられる

\section{$2 \cdot 2$ 電磁場解析によるふく射輸送計算}

ふく射輸送量を求めるためにはグリーン関数を知る必要がある. 弚の求めるべきグリーン関数は, 式 (4) で示さ れるように，放射体内部の各点と観測点を結ぶものである . 放射体内部の点 $\mathbf{r}_{s}$ に周波数 $\omega$ の摇動電流を与えた系 に対して電磁場解析を行うと, 観測点 $\mathbf{r}$ における電磁場と摇動電流の関係が求められる. 兴の電磁場解析では, 放 射体を微小体積要素 $\Delta V$ に分割し，各要素内の摇動電流によって観測点 $\mathbf{r}$ につくられるポインティングベクトルを 求める. このとき $\eta,(\eta=x, y, z)$ 方向の摇動電流が観測点 $\mathbf{r}$ につくるポインティングベクトルを摇動電流強度で規 格化したものを $\mathbf{s}_{\eta}\left(\omega, \mathbf{r}, \mathbf{r}_{s}\right)$ とする .この単位強度摇動電流がつくるポインティングベクトルを用いると，式 (4) で 表されるポインティングベクトルの時間平均值は，

$$
\langle\mathbf{S}(\omega, \mathbf{r})\rangle=2 \frac{\varepsilon_{0} \omega}{\pi} \varepsilon_{r}^{\prime \prime}(\omega) \Theta(\omega, T) \operatorname{Re}\left\{\frac{1}{\Delta V} \sum_{i_{s}, j_{s}, k_{s}}\left[\mathbf{s}_{x}+\mathbf{s}_{y}+\mathbf{s}_{z}\right]\right\} .
$$

のように求められる (付録 B 参照) .

このように観測点 $\mathbf{r}$ におけるポインティングベクトルの時間平均値が式 (5) のように, 放射体を微小要素に分割 したときの各要素のポインティングベクトルの和として与えられることは，式 (3) における空間に関するディラッ クのデルタ関数に起因している (付録 $\mathrm{C}$ 参照) .このことは物体の誘電率が局所的に定義できるというモデルを 用いていることを意味する . このモデルはふく射輸送を求める物体間距離か数ナノメートル以下になるときに修 正を要することが示唆されているものの，乥れ以上の距離については有効である．

$2 \cdot 3$ FDTD 法による放射シミュレーション

放射シミュレーションは, 放射体を微小体積要素に分割したときの各要素に対して，3 方向の電流密度がつくる ポインティングベクトルを求めることによって行われる .このマックスウェル方程式を数值的に解く手法として , 
Absorbing boundary

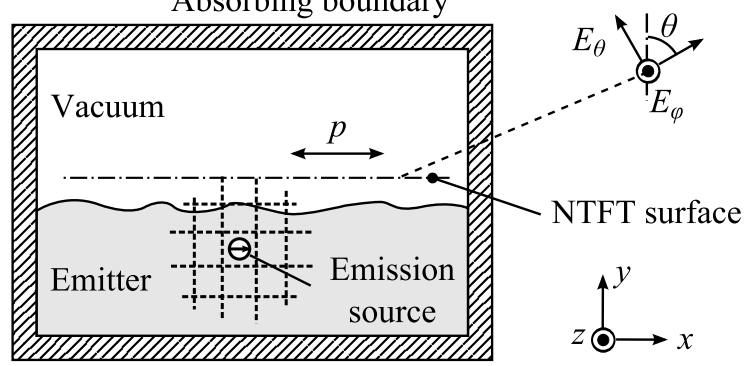

Absorbing boundary

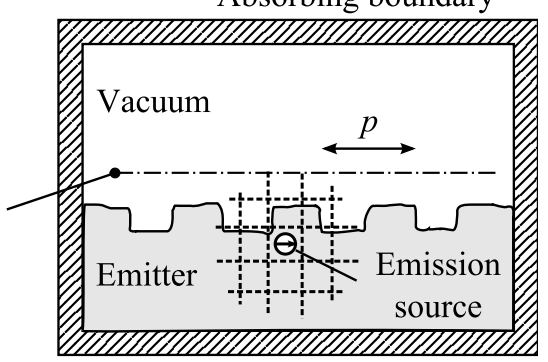

Fig. 2 Schematic diagram of a computational area.

ここでは FDTD 法を用いる ${ }^{(10)}$.この FDTD 法ではマックスウェル方程式のうち以下の 2 式が , 時間領域て離散化 され，計算される．

$$
\begin{aligned}
& \frac{\partial \mathbf{B}}{\partial t}=-\nabla \times \mathbf{E} \\
& \frac{\partial \mathbf{D}}{\partial t}=\nabla \times \mathbf{H}-\mathbf{J}
\end{aligned}
$$

マックスウェル方程式の残りの 2 式については陽に解かれないものの, 初期値としてこれらの条件が満たされて いれば，以降の時刻についても条件を満足する．

図 2 は放射シミュレーションを行うための FDTD 法における計算領域を示す.計算領域の下部は放射体で占め られ，残りは真空で占められている . 図 2 の右は周期 $p$ の構造を有する表面である . 計算領域端には電磁波の反 射を抑制するような吸収境界条件が課されている．FDTD 法では計算資源の制約上，放射体のごく近傍しか扱う ことができない，乥こで放射体近傍の電磁場から放射特性のような十分遠方の電磁場を求める手法として近接場 遠隔場変換 (Near-Field to Far-Field Transformation: NTFT) が用いられる . 以降には, 放射体内部の電磁波伝播計 算方法 , 吸収境界条件, 近接場遠隔場変換の順に关の取扱い方法を述べる.

本研究では, 微細構造表面を用いて放射特性を制御するため, 誘電率が負となる材料が用いられる.負誘電体内 部の電磁波伝播計算は帰納的畳み込み積分法 ( RC 法) が用いられている.この RC 法では, 誘電率分散がドルー デやローレンツモデルとして与えられたとき, 時間領域における電束密度 $D$ が

$$
D(t)=\int_{0}^{t} \varepsilon_{0} \varepsilon_{r}(t-\tau) E(\tau) \mathrm{d} \tau
$$

のように畳み込み積分の形式で求められる. 式中の畳み込み積分の計算には, 微小時間内における電場 $E$ の変化 を線形補間する PLRC 法が用いられる ${ }^{(11)}$.

計算領域の端面で電磁波の反射を抑制するため, 計算領域の周囲 4 面には吸収境界条件か課されている. 弚の吸 収境界条件として, 入射する電磁波の波数を規定する必要がないことおよび時間経過による誤差蓄積が小さいと いう理由から，Perfectly Matched Layer (PML) が用いられている ${ }^{(12)}$. PML は, 計算領域端面において計算領域内 部とほぼ等しい屈折率をもち, 電磁波を吸収する層を複数用いることによって, 端面で電磁波を吸収する手法で ある. 本研究では, 吸収層を 10 層設置し, Second-order PML という手法を用いた ${ }^{(13)}$. この吸収境界条件は, 電 磁波の伝播成分だけでなくエバネッセント成分を吸収させる目的としても導入されている．

放射体から十分遠方の電磁場は, 表面近傍の電磁場分布から近接場遠隔場変換を用いて算出される ${ }^{(14)}$. この近 接場遠隔場変換は, 散乱体を覆う閉曲面上の電磁場から, ガウスの定理やグリーン関数を用いることによって, 遠 方の電磁場を解析的に求める手法である . 遠方における電場は

$$
\begin{aligned}
& E_{\theta}(\omega)=-i \exp (-i k R) \frac{\sqrt{\mu_{0} / \varepsilon_{0}} N_{\theta}(\omega)+L_{\phi}(\omega)}{2 \lambda R} \\
& E_{\phi}(\omega)=i \exp (-i k R) \frac{-\sqrt{\mu_{0} / \varepsilon_{0}} N_{\phi}(\omega)+L_{\theta}(\omega)}{2 \lambda R}
\end{aligned}
$$


と与えられる．ここで, $N, L$ はベクトル

$$
\mathbf{N}(\omega)=\int_{S^{\prime}}(\hat{n} \times \mathbf{H}(\omega)) \exp \left(i k \mathbf{r}^{\prime} \cdot \hat{\mathbf{r}}\right) \mathrm{d} s^{\prime}, \quad \mathbf{L}(\omega)=\int_{S^{\prime}}(\mathbf{E}(\omega) \times \hat{n}) \exp \left(i k \mathbf{r}^{\prime} \cdot \hat{\mathbf{r}}\right) \mathrm{d} s^{\prime},
$$

の極座標系での成分である .ここで $\mathbf{E}(\omega)$ および $\mathbf{H}(\omega)$ は積分面の各点において離散フーリエ変換から求められる 各周波数に対応する複素電磁場である.本研究では图 2 のように放射体が定義されており，放射体を覆う閉曲面 を定義できないため，この閉曲面は表面直上の 1 つの平面 (1 点破線) で代用されている.このとき上式の被積分 関数は電磁場と積分面の法線方向ベクトルの外積を含むため, 近接場遠隔場変換には電磁場の $x$ および $z$ 成分が 用いられている．またFDTD 法では電磁場の定義点が異なるため，積分面上での電磁場は片方を内挿することに よって求められる . 閉曲面をこの 1 平面で代用することに起因する誤差は積分面を十分大きくとることによって 減少する。

近接場遠隔場変換から求めた電場の振幅を 2 乗するとふく射エネルギーに相当する量が求められる .このふく 射エネルギーを, 摇動電流の位置 $\mathbf{r}_{s}$, 方向 $\eta(\eta=x, y, z)$, 周波数 $\omega$, 天頂角 $\theta$ と関連付けて $e_{\eta}^{\prime}\left(\omega, \theta, \mathbf{r}_{s}\right)$ と表す.

\section{$2 \cdot 4$ 放射特性の評価}

遠方での電磁場分布は, 放射体表面近傍の電磁場分布に対し, 上記の近接場遠隔場変換を行うことにより求め られる. このとき図 2 右の周期 $p$ をもつ放射体からある天頂角 $\theta$ に放射される単位面積当たりのふくく射の時間平 均ポインティングベクトル (ふく射エネルギー) は, 各偏光成分について, 周期 $p$ にわたって各微小要素からの放 射を積算することによって

$$
\begin{aligned}
& e^{s}(\omega, \theta)=\frac{1}{p} \sum_{j_{s}=0}^{-\infty} \sum_{i_{s}=0}^{p}\left[e_{z}^{\prime}\left(\omega, \theta, \mathbf{r}_{s}\right)\right] \\
& e^{p}(\omega, \theta)=\frac{1}{p} \sum_{j_{s}=0}^{-\infty} \sum_{i_{s}=0}^{p}\left[e_{x}^{\prime}\left(\omega, \theta, \mathbf{r}_{s}\right)+e_{y}^{\prime}\left(\omega, \theta, \mathbf{r}_{s}\right)\right]
\end{aligned}
$$

と求められる．ここで放射体と金属の境界面に対して，平行な電場をもつ電磁波が $\mathrm{s}$ 偏光（上付き添え字 $s$ )，平 行な磁場をもつ電磁波が $\mathrm{p}$ 偏光（上付き添え字 $p$ ) である . また $\mathbf{r}_{s}$ は放射体内部における微小要素の位置を示し， シミュレーションでの空間刻みを用いて $\mathbf{r}_{s}=\left(i_{s} \Delta x, j_{s} \Delta y\right)$ と表される . このとき, 2 次元計算においては, 放射源 の大きさを定義できないため，式 (4) で示される摇動電流のアンサンブル平均を定量的に与えることが難しい，光 のため放射率は同じ媒質で構成された参照表面の垂直ふく射エネルギー (下付き添え字 $N$ ) を計算し，弚の值が 垂直単色放射率に対応することを用いて規格化され，以下のように算出される．

$$
\begin{aligned}
& \varepsilon^{s}(\omega, \theta)=\varepsilon_{N}^{r e f}(\omega) \frac{e^{s}(\omega, \theta)}{e_{N}^{r e f}(\omega)} \frac{1}{\cos \theta} \\
& \varepsilon^{p}(\omega, \theta)=\varepsilon_{N}^{r e f}(\omega) \frac{e^{p}(\omega, \theta)}{e_{N}^{r e f}(\omega)} \frac{1}{\cos \theta}
\end{aligned}
$$

式中の $\cos \theta$ は投影面積を表す．また，ここでは参照面としてふく射機能性表面と同じ媒質の平滑面（光学鏡面） が用いられている.

\section{3. 放 射 特 性}

$3 \cdot 1$ ニッケル金属平滑面の指向性単色放射率

金属平滑面の指向性単色放射率は偏光によって大きく異なる . 境界面に並行な電場成分をもつ $\mathrm{s}$ 偏光において指 向性放射率は，垂直方向で最大值をとり，天頂角が大きくなるにつれて単調減少する，一方，境界面に平行な磁場 成分をもつ $\mathrm{p}$ 偏光において指向性放射率は, ある天頂角で最大値をとる．ここで, 単位面積当たりの指向性うく 射エネルギーの計算式 (12), (13) は, 周期を考慮する必要がないため, 以下のように簡略化される .

$$
\begin{aligned}
& e^{s}(\omega, \theta)=\frac{1}{\Delta x} \sum_{j_{s}=0}^{-\infty} e_{z}^{\prime}\left(\omega, \theta, \mathbf{r}_{s}\right), \\
& e^{p}(\omega, \theta)=\frac{1}{\Delta x} \sum_{j_{s}=0}^{-\infty}\left[e_{x}^{\prime}\left(\omega, \theta, \mathbf{r}_{s}\right)+e_{y}^{\prime}\left(\omega, \theta, \mathbf{r}_{s}\right)\right] .
\end{aligned}
$$




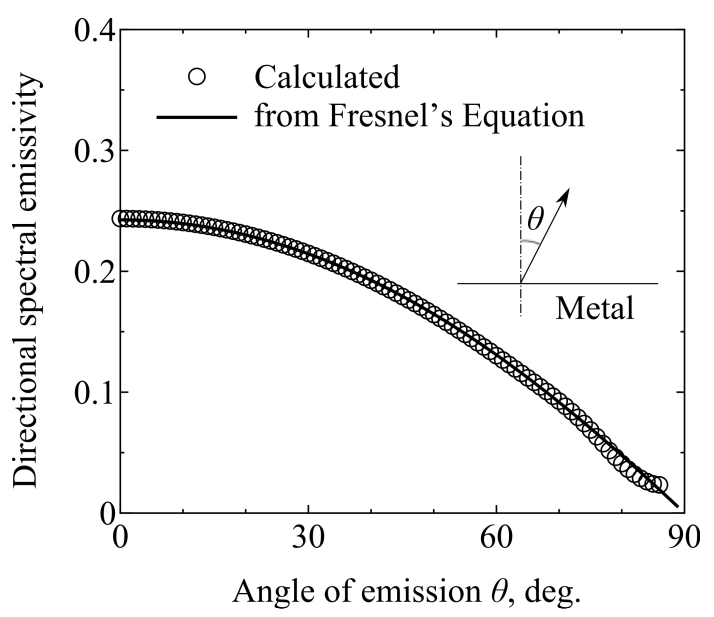

Fig. 3 Directional spectral emittance of Nickel's specular surface for s-polarization at $\lambda=1.0 \mu \mathrm{m}$.

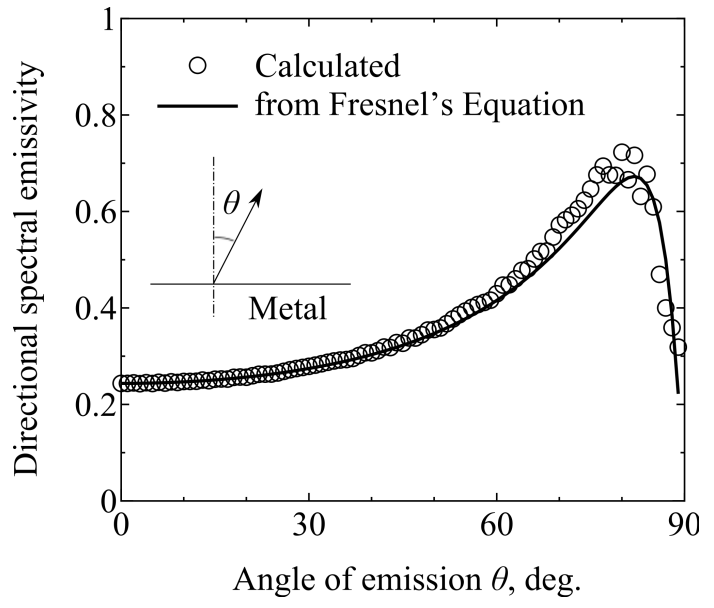

Fig. 4 Directional spectral emittance of Nickel's specular surface for p-polarization at $\lambda=1.0 \mu \mathrm{m}$.

また平滑面の指向性単色放射率は垂直方向のふくく射エネルギーで規格化することによって以下のように求められる．

$$
\begin{aligned}
& \varepsilon^{s, N i, s p e c}(\omega, \theta)=\varepsilon_{N}^{N i, s p e c}(\omega) \frac{e^{s, N i, s p e c}(\omega, \theta)}{e_{N}^{s, N i, s p e c}(\omega)} \frac{1}{\cos \theta}, \\
& \varepsilon^{p, N i, s p e .}(\omega, \theta)=\varepsilon_{N}^{N i, s p e c}(\omega) \frac{e^{p, N i, s p e c}(\omega, \theta)}{e_{N}^{p, N i, s p e c}(\omega)} \frac{1}{\cos \theta} .
\end{aligned}
$$

ここで $\varepsilon_{N}^{N i, s p e c}(\omega)$ は与えられた金属の屈折率から求められる垂直放射率である . なお , ニッケルの誘電率分散に は 2 極ドルーデモデルを用いた ${ }^{(15)}$.

図 3 は波長 $\lambda=1.0 \mu \mathrm{m}$ におけるニッケル金属平滑面の $\mathrm{s}$ 偏光に関する指向性単色放射率を示す . 図 3 には計算 結果に加えて，フレネルの式から得られる指向性単色放射率 $\varepsilon^{N i, s p e c}(\omega, \theta)$ も記されている . 点状の放射源を仮定 した放射シミュレーション結果は，平面波の入射から求められる結果に等しいことがわかる．

一方，図 4 は波長 $\lambda=1.0 \mu \mathrm{m}$ ニッケル金属平滑面の $\mathrm{p}$ 偏光に関する指向性単色放射率を示す . 図に示される計 算結果は大きな天頂角において放射率の最大值となる $\mathrm{p}$ 偏光の特性をよく表している．しかし角度が大きくなる につれて物性から求められる指向性放射率との差が増大した . これは放射率を算出する過程で投影面積で除すこ とに由来する . また結果の小さな変動は, 式 (11) 直後の議論のように, 近接場遠隔場変換の積分面を平面で代用 したために生じたものである .

ふく射エネルギーを求めるとき, 定量的には式 (16)，(17)のように積算が必要となる . 一方, 弚の放射体の性質 は，積算のひとつの要素である，放射体内部におけるひとつの放射源がつくる電磁場分布に起因することが多い． 本研究では磁性を有する媒質を用いていないため, 表面構造の影響は電場分布に反映される . 図 5(a) は $z$ 方向の 


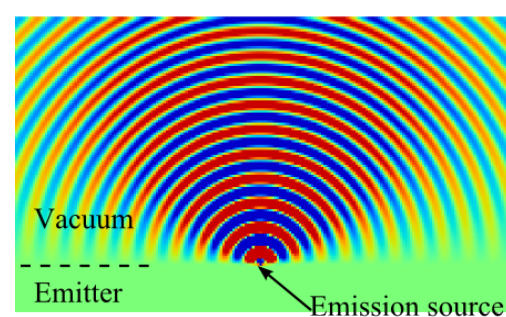

(a) $E z$ distribution around an emission source with the direction of $z$. (s polarization)

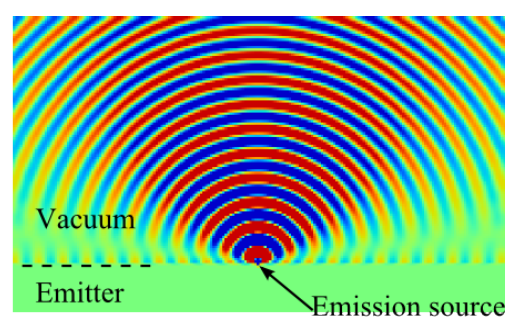

(b) Ex distribution around an emission source with the direction of $x$. (p polarization)

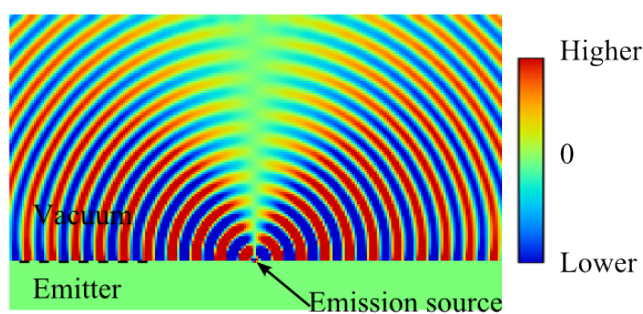

(c) Ey distribution around an emission source with the direction of $x$. (p polarization)

Fig. 5 Electric field distribution around the radiation source at $\lambda=1.0 \mu \mathrm{m}$.

放射源によって誘起された電場の $z$ 成分の分布を示し, $\mathrm{s}$ 偏光の特性を表す . 点線は金属と真空の境界面を表し， 放射源は矢印で示された位置にある．電場は放射源を中心として同心円状に分布していることが分かる．一方， $\mathrm{p}$ 偏光の特性として， $x$ 方向の放射源によって誘起された，電場の $x$ 成分を図 $5(\mathrm{~b})$ に，電場の $y$ 成分を図 $5(\mathrm{c})$ に示 す. 図 5(b) では, (a) の $\mathrm{s}$ 偏光と比較すると，放射源を中心とした同心円状の電場分布か境界面付近でゆがんでい る.このゆがみは，金属と真空の境界面近傍に誘起される表面プラズモンポラリトンの波数と，真空中の波数がー 致しないために生じる . 表面波は面に垂直方向の電場には寄与しないため , 図 5(c) は同心円状の電場分布となる

\section{$3 \cdot 2$ 薄膜系の指向性単色放射率}

放射面に対して垂直方向に屈折率変化を与えて放射特性を制御する方法の例として，図 6 のような単層透明薄 膜の指向性単色放射率を求めた . 放射体はニッケル金属表面に透明薄膜を積層させた構造とした . 透明薄膜の厚さ は $d=0.9 \mu \mathrm{m}$ ，屈折率は $n=2.0$ とした ${ }^{(2)}$. また透明薄膜は吸収が非常に小さいため，薄膜からの放射は考慮しな いものとする．この放射体では，薄膜と空気界面およひ溥膜と金属界面で電磁波が多重反射し干渉することによっ て放射特性が制御される.薄膜系の指向性ふくく射エネルギ一は平滑面と同樣に式 (16), (17) で求められる.さらに 指向性単色放射率は, ニッケル平滑面の垂直ふく射エネルギーを用いて規格化され，以下のように求められる.

$$
\begin{aligned}
& \varepsilon^{s, F}(\omega, \theta)=\varepsilon_{N}^{N i, s p e c}(\omega) \frac{e^{s, F}(\omega, \theta)}{e_{N}^{N i, s p e c}(\omega)} \frac{1}{\cos \theta} \\
& \varepsilon^{p, F}(\omega, \theta)=\varepsilon_{N}^{N i, s p e c}(\omega) \frac{e^{p, F}(\omega, \theta)}{e_{N}^{N i, s p e c}(\omega)} \frac{1}{\cos \theta}
\end{aligned}
$$

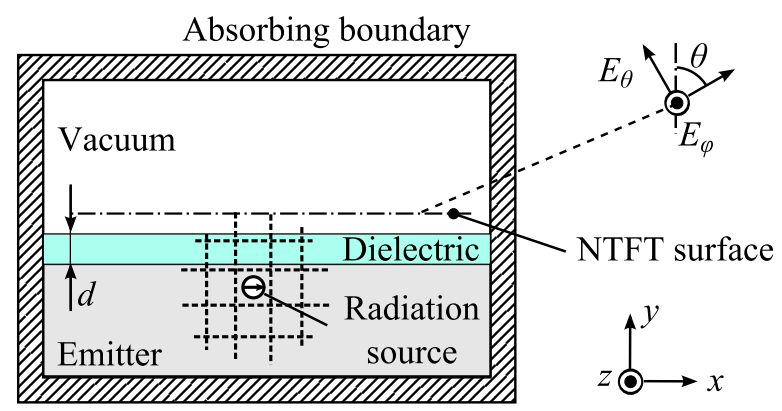

Fig. 6 Shematic diagram of a metallc emitter with transparent-thin film.

図 7 はこの薄膜系の垂直単色放射率を示す. 图 7 にはFDTD 法を用いた計算結果に加えて, 平面波の垂直入射 垂直反射率を用いて垂直放射率を算出した值と牧野らによって計測された結果 ${ }^{(2)}$ を示す. 放射シミュレーションは $\mathrm{s}, \mathrm{p}$ の各偏光について行われたが，両者の垂直単色放射率は同一の值を示した . 計算結果は反射率から算出された 放射率とよく一致し，物体内部の点状放射源からの放射が干渉することを示した．また計算結果は, 牧野らの実 験結果とも定性的にかつ一部定量的にも一致している. 


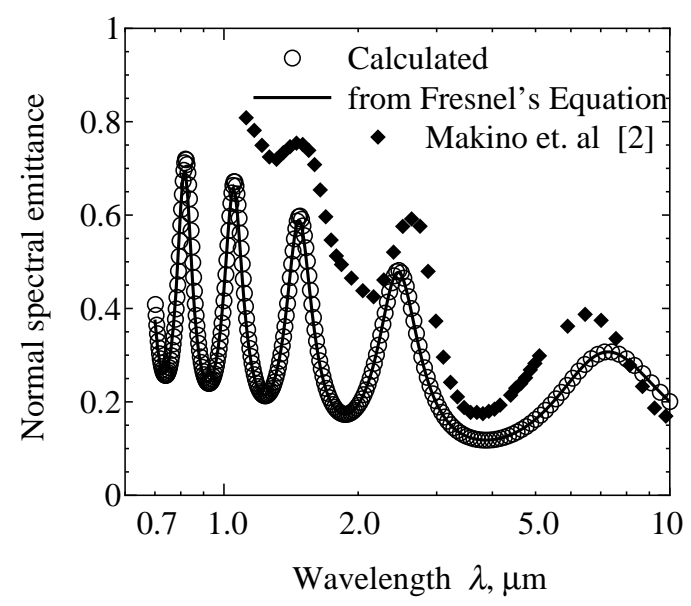

Fig. 7 Normal spectral emittance of Nickel's specular surface covered with transparent thin-film.

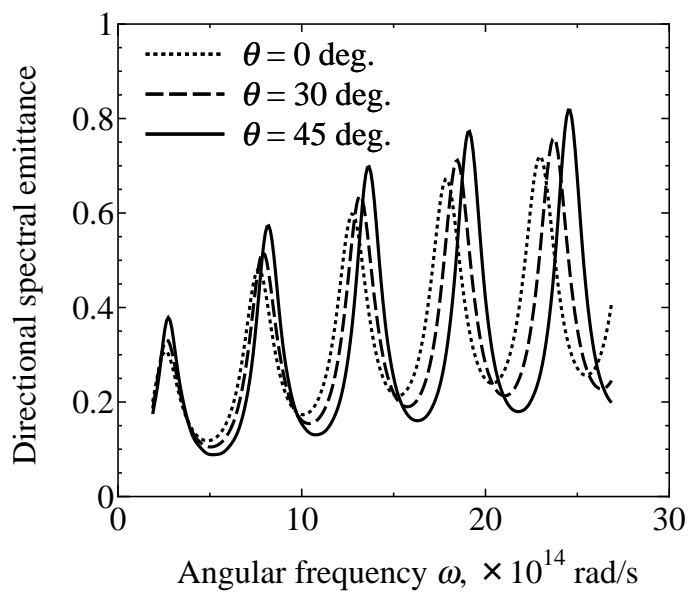

Fig. 8 Directional spectral emittance of Nickel's specular surface with transparent thin-film for s-polarization.

図 8 には, $\mathrm{s}$ 偏光に対する薄膜系の指向性単色放射率が, 天頂角の 3 条件 $\theta=0^{\circ}, 30^{\circ}, 45^{\circ}$ について示されてい る.ここで放射率の最大值を与える角度の推移を示すため，横軸を角周波数とした．弚の放射率の最大値を与え る角度は天頂角が大きくなるにつれて高周波数側すなわち短波長側に推移することが分かる . また放射率の極大 值と極小值間の差は , 天頂角が大きくなるにつれて大きくなっている .

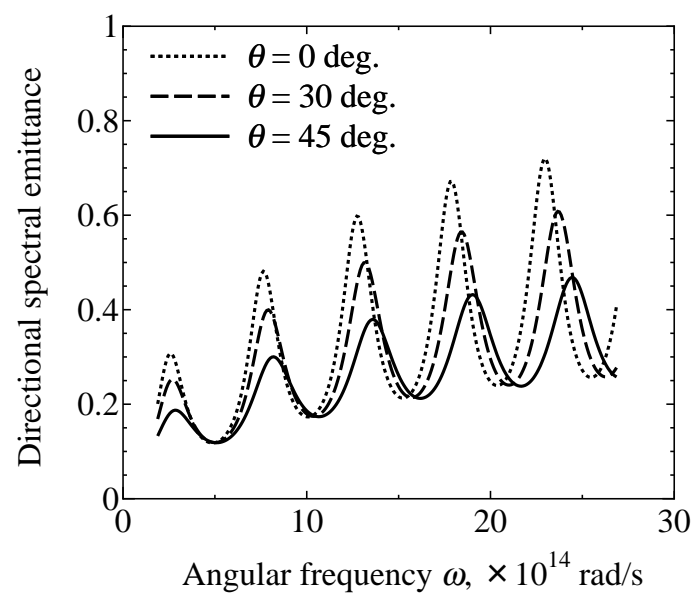

Fig. 9 Directional spectral emittance of Nickel's specular surface with transparent thin-film for p-polarization. 
一方, 图 9 は $\mathrm{p}$ 偏光に対する薄膜系の指向性単色放射率である $\cdot \mathrm{p}$ 偏光の特性は, 放射率の極大值を与える角度 が天頂角の増加とともに高周波数側に推移する点で $\mathrm{s}$ 偏光と同樣であるが , 放射率の極大値と極小值間の差が天頂 角の増加と共に小さくなる点で $\mathrm{s}$ 偏光と異なる . この差は，薄膜と金属界面の局所的な反射率とともに増大する． 局所的な反射率が小さい場合，金属から薄膜へ放射する電磁場の振幅に比べて薄膜・真空界面で反射した電磁波 の振幅が小さいため渉の効果が小さい，一方，局所的な反射率が大きい場合，千渉の効果か顕著になる .

図 10 は各偏光の和をとったときの指向性放射率を示す. 弚れ光れの偏光では指向性単色放射率の極大值と極小值 間の差が放射角度 $\theta$ と共に大きく变化したものの，各偏光の和をとると放射率の振幅は角度依存性が小さくなる．

ふく射の干渉挙動と電磁場分布の関係を考察する.図 11 に $\mathrm{s}$ 偏光における， $z$ 方向の放射源まわりの $E_{z}$ を示す. 図 11(a) は，垂直単色放射率の極大值のひとつである，波長 $\lambda=1.47 \mu \mathrm{m}$ の電場分布，図 11(b) は，垂直単色放射 率の極小值のひとつである , 波長 $\lambda=1.87 \mu \mathrm{m}$ の電場分布である . 両図には電場分布に加えて各波長における薄膜 系の指向性単色放射率か極座標系で示されている . 図 11(a) は真空中の同心円状電場分布と真空・薄膜界面の電場 分布が同位相になっており，これが強め合う条件となっている.一方，図 11(b) では，真空中の同心円状電場分布 が真空と薄膜界面近傍で歪んでいる．この電場分布の歪みは，乥の界面を挟んで真空中の電場の位相と薄膜中の 電場の位相が逆になっているために生じる .このような条件では薄膜干渉は電場を弱めるように作用している．

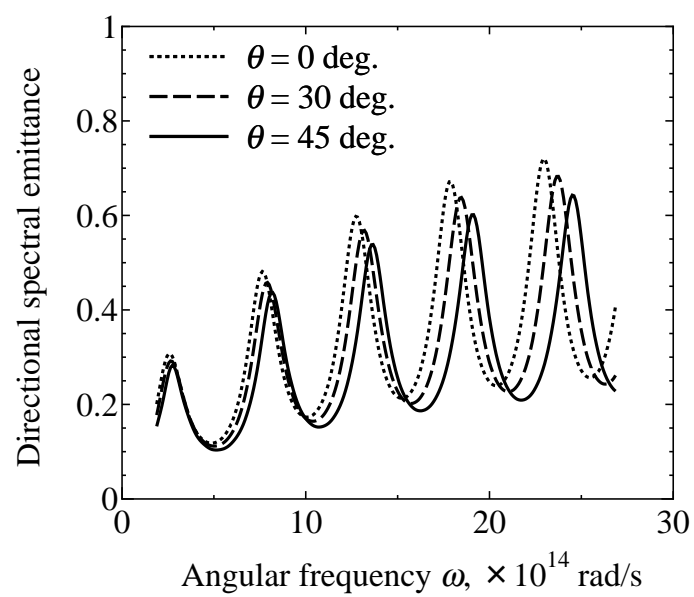

Fig. 10 Directional spectral emittance of Nickel's specular surface covered with transparent thin-film.

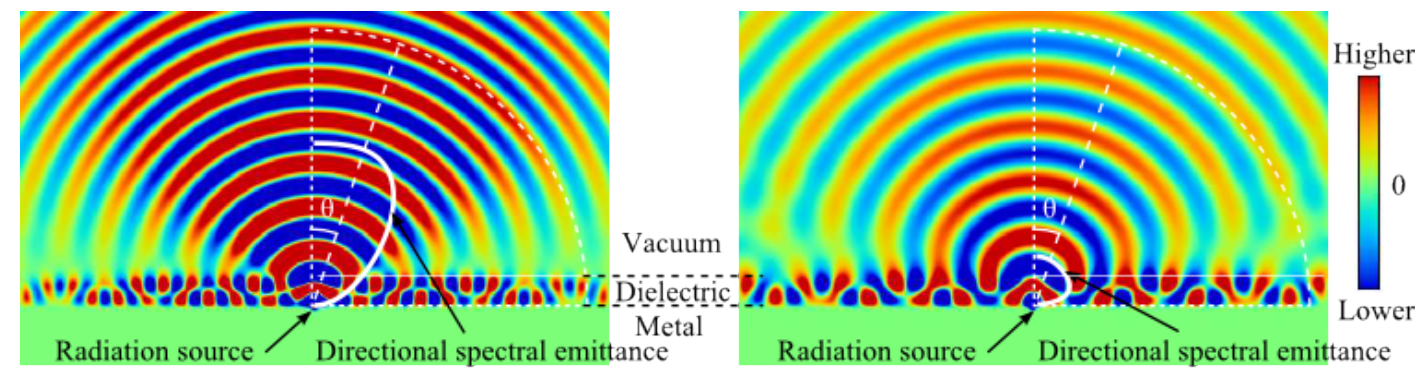

(a) $\lambda=1.47 \mu \mathrm{m}\left(\omega=12.8 \times 10^{14} \mathrm{rad} / \mathrm{s}\right)$

(b) $\lambda=1.87 \mu \mathrm{m}\left(\omega=10.1 \times 10^{14} \mathrm{rad} / \mathrm{s}\right)$

Fig. 11 Electric field distribution around Nickel's specular surface covered with transparent thin-film.

\section{$3 \cdot 31$ 次元格子系の指向性単色放射率}

面方向に周期的屈折率変化を与える 1 次元格子系を考える. 放射特性を制御するもう一つの方法として, Greffet $ら^{(5)}$ は炭化ケイ素 $(\mathrm{SiC})$ 表面に図 12 のような浅い溝構造を施すことによって，磁場が溝に平行な $\mathrm{p}$ 偏光成分に ついて特定の角度で放射率か増大することを示した .この放射体では, 溝に平行な磁場をもつ $\mathrm{p}$ 偏光の電磁波成 分において金属表面に誘起される表面波が，周期構造により周期的な電磁場を空気中に誘起し，乥の電磁場が空 気中を伝播する散乱光を形成することによって放射特性か制御される $\cdot \mathrm{p}$ 偏光では誘電率の符号が異なる界面にお 


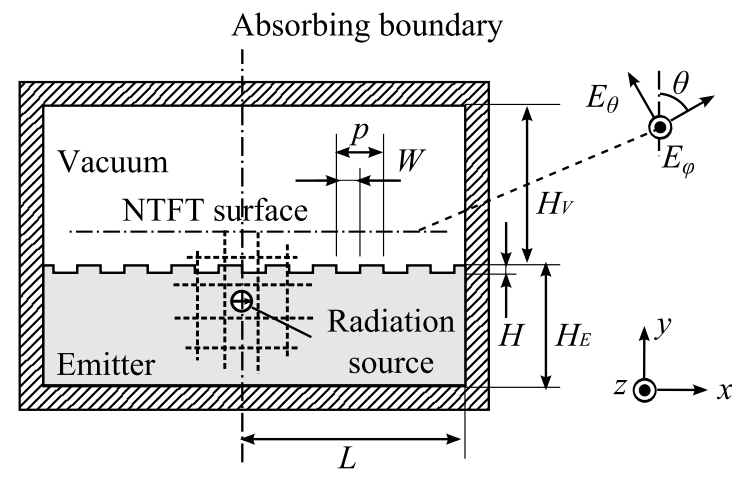

Fig. 12 Schematic diagram of the shallow-grooved surface emitter.

いて, 波数が

$$
k_{\|}=\frac{\omega}{c_{0}} \sqrt{\frac{\varepsilon_{D} \varepsilon_{M}}{\varepsilon_{D}+\varepsilon_{M}}}
$$

となる表面波が誘起される .ここで $\varepsilon_{D}$ は誘電率が正の媒質を， $\varepsilon_{M}$ は誘電率が負の媒質を表す . この表面波が周 期 $p$ の表面構造と相互作用し, 天頂角 $\theta$ について以下の条件

$$
k_{0} \sin \theta=k_{\|}+m \frac{2 \pi}{p}, \quad m=0, \pm 1, \pm 2, \cdots
$$

が満たされるときこの方向 $\theta$ に散乱光が生じる .

面方向に周期 $p$ をもつとき，指向性ふく射エネルギーは次のように求められる .

$$
e^{p, G}(\omega, \theta)=\frac{1}{p} \sum_{j_{s}=0}^{-\infty} \sum_{i_{s}=0}^{p / \Delta x}\left[e_{x}^{\prime}\left(\omega, \theta, \mathbf{r}_{s}\right)+e_{y}^{\prime}\left(\omega, \theta, \mathbf{r}_{s}\right)\right] .
$$

ここで上付き文字 $G$ は格子構造の特性を表す .この構造の指向性単色放射率は, 構造面のふくく射エネルギーが平 滑面の垂直ふく射エネルギーで規格化されることにより次のように求められる .

$$
\varepsilon^{p, G}(\omega, \theta)=\varepsilon_{N}^{S i C, s p e c}(\omega) \frac{e^{p, S i C, G}(\omega, \theta)}{e_{N}^{p, S i C, s p e c}(\omega)} \frac{1}{\cos \theta}
$$

格子構造のパラメタは, 基準波長を $\lambda_{0}=11.4 \mu \mathrm{m}$ として , 周期 $p=0.55 \lambda_{0}$, 溝の幅 $W=0.5 d$, 溝の深さ $H=\lambda_{0} / 40$ である . 計算領域はエミッタ厚さ $H_{E}=\lambda_{0}$, 真空領域高さ $H_{V}=\lambda_{0}$, エミッタの面方向長さ $L=30 \lambda_{0}$ である . こ のとき炭化ケイ素の誘電率分散にはローレンツモデルを用いた ${ }^{(16)}$. 図 13 は波長 $\lambda=11.4 \mu \mathrm{m}$ における炭化ケイ素 表面に施された格子構造の指向性単色放射率である .なお，放射シミュレーションから得られた値とともにフレ ネルの式を用いて算出された值も記されている.計算によって求められた平滑面の指向性単色放射率とフレネル の式から求められたものの差は放射角度が大きくなるにつれて増大した . これは表面波の減衰長が非常に大きい ため，計算領域の大きさが十分でないことが原因である．また，計算領域端における表面波の吸収が十分でなく， 表面波の一部か計算領域に反射している樣子が確認されている．この表面波を吸収させる手法として，放射体と 吸収境界の間にインピーダンス整合層 (Impedance Matching Layer: IML) を導入する方法が検討されている ${ }^{(17)}$.

格子構造の指向性単色放射率は角度 $\theta=49.4^{\circ}$ 付近でのみ平滑面に比べて放射率が高く，他の角度域では平滑面 と同等の放射率である.一方，周期構造によって表面波が放射される角度を式 (23) から求めると $\theta=51.3^{\circ}$ であ る.ここで表面波の波数べクトルは平滑面表面に誘起されるものを与えた . この式 (23) から求められる放射角度 は計算結果における放射率の最大值を与える角度に近い値である．

格子構造が電磁場分布に与える影響を考察するため, 図 14 に平滑面と格子構造まわりにおける電場の $x$ 成分 (面方向成分) を示す．このとき放射源の位置は矢印で示されており，これらの位相は等しい．図 14(a)の平滑面 まわりの電場が同心円状に分布しているのに対し, 図 14(b) の格子構造まわりの電場はわずかにゆがんでいる .

表面構造による電場分布の差異を求めるため, 各格子点における電場の差 $\Delta E_{x}(i, j)=E_{x}^{G}(i, j)-E_{x}^{s p e c}(i, j)$ を図 15(a) に示す . 図中の実線は放射率の最大值を与える角度を示し，この方向に平面波のような分布が形成されてい 


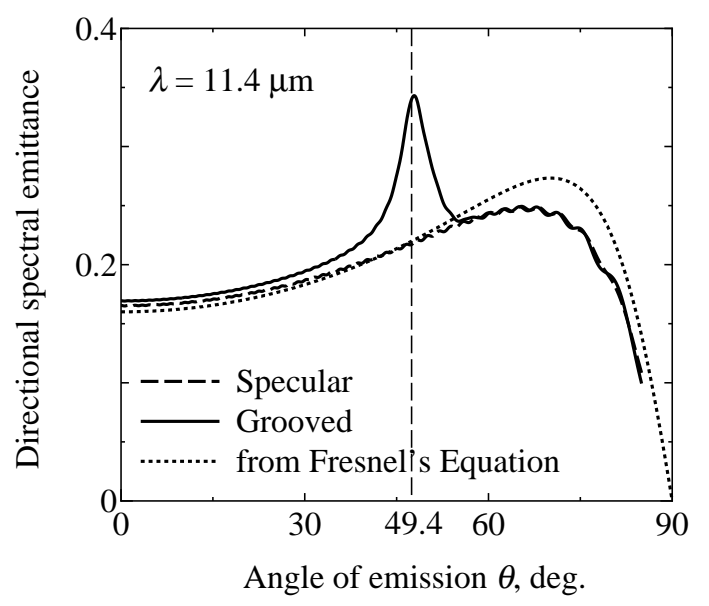

Fig. 13 Directional spectral emittance of grooved SiC surface for the wavelength of $11.4 \mu \mathrm{m}$.

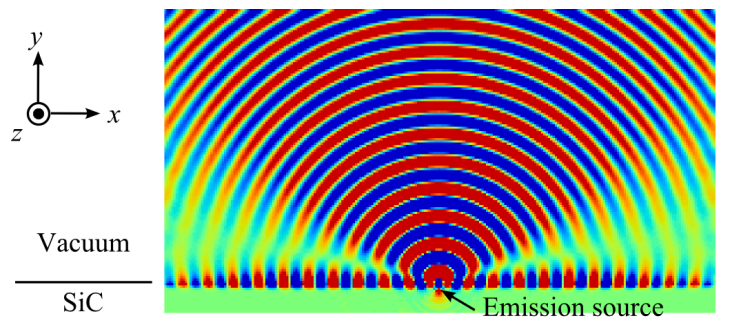

(a) Specular surface

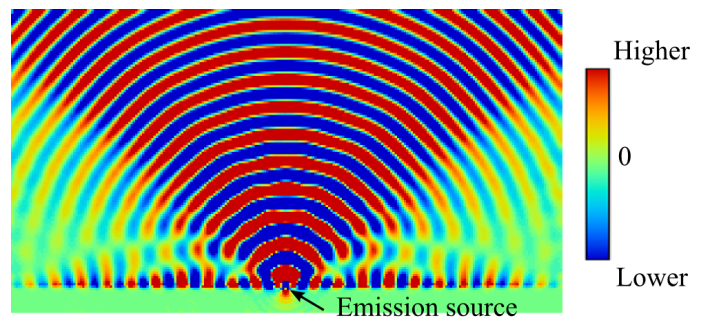

(b) Shallow-grooved surface

Fig. 14 Distibution of $E_{x}$ around the specular surface and the grooved surface.

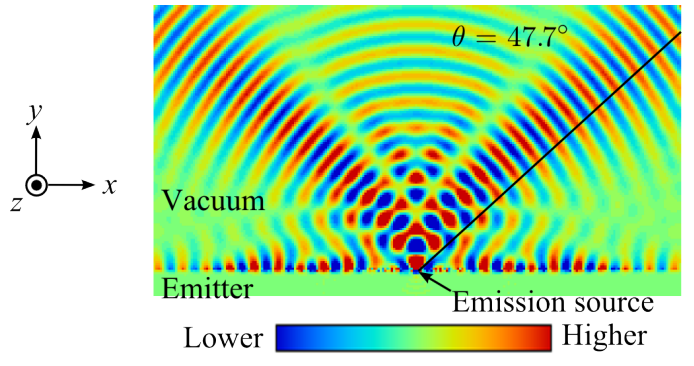

(a) $\Delta E_{x}(i, j)$

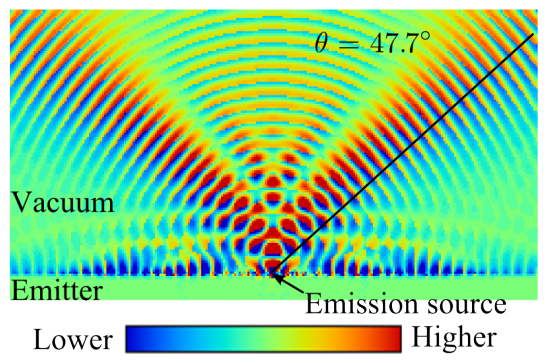

(b) $\Delta E_{x}(i, j) \frac{E_{x}^{\operatorname{spec}}(i, j)}{\left|E_{x}^{s p e c}(i, j)\right|}$

Fig. 15 Difference of $E_{x}$ between the specular surface and the grooved surface.

る.したがって図 14(b) の電場分布は, 平滑面まわりの分布と図 15 に示される平面波の分布の和に分解される . ま た，電場振幅の増減を求めるため，電場の差に平滑面の電場の符号を乗じたものが図 15(b) である. 図 15(b) の赤 い領域は，平滑面の分布と比較して電場振幅が増大することを，青い領域は電場振幅が減少することを表す．先 に示した放射率の最大值を与える角度方向に電場振幅の増大する領域が分布しているのに対し，表面に沿って電 場振幅の減少する領域が分布している．したがって表面波のエネルギーが周期構造に散乱されて伝播光のエネル ギーへ変換されていることがわかる .

以上のことから浅い溝構造の放射特性は, 平滑面の特性に表面波の散乱効果が付与されたものと考えられる .こ のとき式 (23) を用いると，平滑面における表面波の波数べクトルと浅い溝構造の周期から算出される散乱角度は， 図 13 で表されるように，浅い溝構造の指向性単色放射率の極大值を与える角度によく一致する.このような，指 向性単色放射率の極大值を与える角度と式 (23) の関係をいくつかの周波数に対して求めた結果が図 16 である. 図 16 の縦軸は周波数であり，横軸は式 (23) を示す . 図 16 には浅い溝構造について放射率の極大值を与える角度か ら式 (23) の左辺 $\left(k_{0} \sin \theta\right)$ を求めたものがシンボルにて記され，同時に平滑面の表面波の波数べクトルを用いて式 


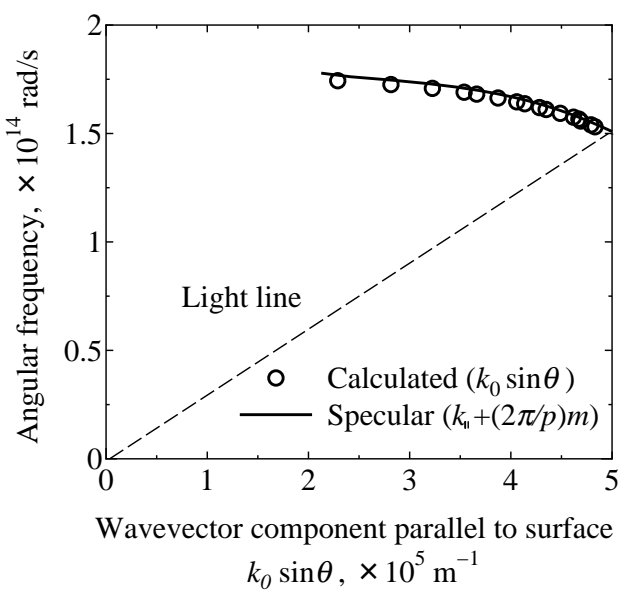

Fig. 16 Dispersion relation of surface wave induced around grooved SiC surface.

(23)の右辺を求めた結果が実線にて記されている.この結果から，計算によって求められた浅い溝構造における 表面波の分散関係は平滑面における弚れとほぼ等しく，平滑面の放射特性を基本としていることが分かる．した がって, 浅い溝構造の放射特性は, 基本的には平滑面の放射特性に, 平滑面に生じる表面波の散乱効果が付加さ れたものと考えることができる．

\subsection{1 次元構造の放射制御}

薄膜系，格子系について熱ふく射の放射という観点から放射制御について考察する．図 17 は $2 つ の 1 / 4$ 円から 構成され，上部は指向性単色放射率を極座標系で表したもの，下部は金属内部を伝播して境界面に到達した電磁波 エネルギーに対する，真空へ放射するエネルギーの分布図である . 図 17 の下部における動径方向の点線は金属 · 真空界面の臨界角を表す . 図 17 における赤線上の任意の点は, 動径と縦軸のなす角度が, 上部では放射角度 , 下 部では入射角度を表し，原点からの距離が，上部では放射率，下部では放射への寄与の大きさを示す．(a) は金属 平滑面，(b) は薄膜系， (c) は1 次元格子系についての結果である.

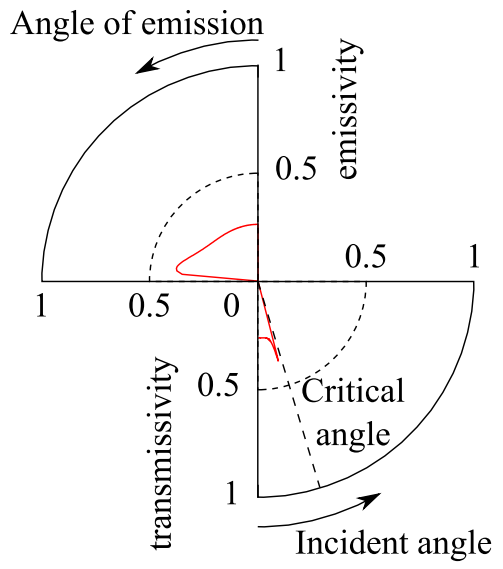

(a) specular metal

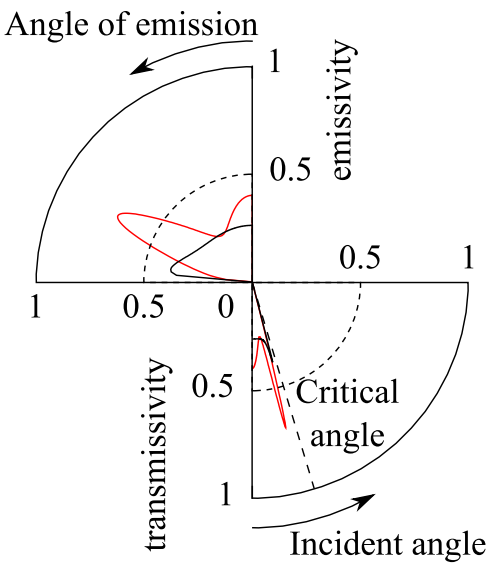

(b) specular metal with a thin layer

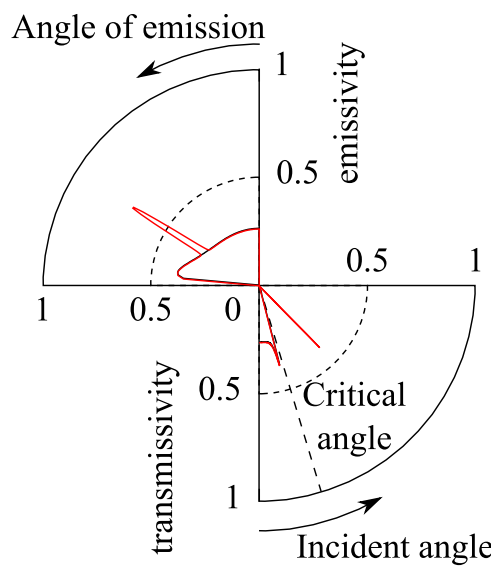

(c) metallic grating

Fig. 17 Control emission of thermal radiation for one-dimensional structures.

図 17(a)の金属平滑面について, 上部の指向性放射率は垂直方向からある程度の天頂角までほぼ一定値を示し，大 きい天頂角で極大值をとる．また，下部の臨界角より小さい角度で入射した電磁波が熱うく射の放射入寄与する． 一方，臨界角より大きい角度で入射した電磁波は全反射するため真空中へは放射されない，図 17(a)の下部は上部 が圧縮されたものであり，入射角度と放射角度はスネルの法則を用いて1対 1 に対応する． 
図 17(b) は薄膜系の放射特性である.ここで黑実線は図 17(a)に示された，金属平滑面の放射特性である．薄膜 系の放射特性は, 平滑面と同樣に, 平面波に対する応答と同樣に表現でき ${ }^{(18)}$, 金属と真空の間に透明膜が存在す ることにより放射率が増加する．さらに金属内部を伝播し金属・薄膜界面に入射した電磁波と，薄膜・真空界面 で反射し金属・薄膜界面に入射した電磁波が干渉する．このとき，放射する角度によって薄膜内で生じる位相差 か変化するため，放射角度によって放射率か増減する．薄膜系の金属・薄膜界面へ入射する電磁波の放射入の寄 与と指向性単色放射率との角度に関する対応関係は図 17(a)の金属平滑面と同樣，スネルの法則で与えられる .

図 17(c) は格子系のp 偏光に関する特性を示したものである. 本論文で用いられたような溝の浅い格子系では， 下部の臨界角より小さい角度の性質は图 17(a)で示された金属平滑面と同等の特性をもつと考えられる. 图 16 と も対応する格子系で表面波を放射に寄与させることは，図の臨界角より大きい角度をもつ成分を放射させること を意味する . この寄与は指向性放射率の極大值に反映され，入射角度と放射角度の対応は式 (23) と表面波の誘起 条件 $k_{\|}=k_{m} \sin \theta_{i}$ から導かれる.ここで $k_{m}$ は金属内部の波数， $\theta_{i}$ は金属内部を伝播した電磁波の界面への入射角 度である。

このように 1 次元構造の薄膜系と格子系は全く異なる概念で放射制御が行われている．薄膜系は，金属平滑面 と同樣にスネルの法則で説明でき，放射する程度を増減させる手法である．一方，格子系は，本来，放射に寄与 しない成分を，周期構造を導入することによって，放射させる手法である．このことから薄膜系と格子系とを組 み合わせた新規な放射制御の可能性も示唆しているといえる.

\section{4. 結 論}

摇動電磁気学に基づいた放射シミュレーション方法を構築し，2 次元の系においてふく射機能性表面の放射特性 を求めた . 面に垂直方向に屈折率か湾化する薄膜系において点状の放射源からの放射が干渉することを示した . こ のとき $\mathrm{s}$ 偏光と $\mathrm{p}$ 偏光の指向性放射率を比較することによって, 干渉の振幅が金属・透明薄膜界面の局所的な反 射率とともに増大することが示された . また，半導体材料である炭化ケイ素でも金属のように振る舞う波長域を 選択することによって, 面方向に周期的屈折率変化が与えられる格子系において, 表面波と周期構造の相互作用 による散乱光の発生が表現できることが示された．乥して，ここで開発された放射シミュレーションにより得ら れた放射源まわりの電磁場分布は放射体の指向性放射率の特性をよく表すことが示された．この手法を用いるこ とで, 薄膜系と 1 次元格子系による放射制御の特徵が, ふく射の放射といった観点から, 視覚的に理解できるこ とが示された。

謝 辞

本研究の一部は日本学術振興会・特別研究員奨励費および科学研究費補助金 [基盤研究 (B) No. 21360094] によっ て遂行された 、ここに記して謝意を表す。

\section{Appendix A}

式 (3) で表される電流密度のアンサンブル平均を用いてポインティングベクトルの時間平均值を導出する.$\alpha$ 方 向の電場と $\beta$ 方向の磁場の相関関数は,

$$
\left\langle H_{\beta}^{*}\left(\mathbf{r}^{\prime}, \omega^{\prime}\right) E_{\alpha}(\mathbf{r}, \omega)\right\rangle=\operatorname{Re}\left\{i \omega \mu_{0} \int_{V} \mathrm{~d} \mathbf{r}_{s 2}^{\prime} \int_{V} \mathrm{~d} \mathbf{r}_{s 1}^{\prime}\left\langle\left\{J_{x}^{s *} G_{\beta x}^{H *}+J_{y}^{s *} G_{\beta y}^{H *}+J_{z}^{s *} G_{\beta z}^{H *}\right\}\left\{J_{x}^{s} G_{\alpha x}^{E}+J_{y}^{s} G_{\alpha y}^{E}+J_{z}^{s} G_{\alpha z}^{E}\right\}\right\rangle\right\}
$$

である .ここでグリーン関数の下付き文字は行列の成分を表す.式 (3) にディラックのデルタ関数とクロネッカー のデルタが含まれていることを用いると，

$$
\left\langle H_{\beta}^{*}(\mathbf{r}, \omega) E_{\alpha}(\mathbf{r}, \omega)\right\rangle=\frac{\varepsilon_{0} \omega}{\pi} \varepsilon_{r}^{\prime \prime}(\omega) \Theta(\omega, T) \operatorname{Re}\left\{i \mu_{0} \omega \int_{V} \mathrm{~d} \mathbf{r}_{s}^{\prime 3}\left\{G_{\beta x}^{H *} G_{\alpha x}^{E}+G_{\beta y}^{H *} G_{\alpha y}^{E}+G_{\beta z}^{H *} G_{\alpha z}^{E}\right\}\right\},
$$

となる . 上式の被積分関数を $G_{\beta x}^{H *} G_{\alpha x}^{E}+G_{\beta y}^{H *} G_{\alpha y}^{E}+G_{\beta z}^{H *} G_{\alpha z}^{E}=G_{\beta l}^{H *} G_{\alpha l}^{E}$ と表すと, 観測点 $\mathbf{r}$ におけるポインティング ベクトルの時間平均値は

$$
\langle\mathbf{S}(\omega, \mathbf{r})\rangle=2 \frac{\varepsilon_{0} \omega}{\pi} \varepsilon_{r}^{\prime \prime}(\omega) \Theta(\omega, T) \operatorname{Re}\left\{i \mu_{0} \omega \int_{V} \mathrm{~d} \mathbf{r}_{s}^{3}\left[\begin{array}{l}
G_{z l}^{H *} G_{y l}^{E}-G_{y m}^{H *} G_{z m}^{E} \\
G_{x l}^{H *} G_{z l}^{E}-G_{z m}^{H *} G_{x m}^{E} \\
G_{y l}^{H *} G_{x l}^{E}-G_{x m}^{H *} G_{y m}^{E}
\end{array}\right]\right\}
$$


のように求められる.電場に関するグリーン関数 $G^{E}$ と磁場に関するグリーン関数 $G^{H}$ はともにある周波数 $\omega に$ 関して，観測点 $\mathbf{r}$ と一つ放射源位置 $\mathbf{r}_{s}$ を結ぶものである .

\section{Appendix $\quad$ B}

式 (1) を離散化すると, 点 $\mathbf{r}_{s}$ の微小体積要素 $\Delta V$ 内の $\eta$ 方向, 周波数 $\omega$ の摇動電流か観測点 $\mathbf{r}$ につくる電場は

$$
\mathbf{E}_{\eta}^{\prime}\left(\omega, \mathbf{r}, \mathbf{r}_{s}\right)=\left[\begin{array}{c}
E_{x \eta}^{\prime}\left(\omega, \mathbf{r}, \mathbf{r}_{s}\right) \\
E_{y \eta}^{\prime}\left(\omega, \mathbf{r}, \mathbf{r}_{s}\right) \\
E_{z \eta}^{\prime}\left(\omega, \mathbf{r}, \mathbf{r}_{s}\right)
\end{array}\right]=i \mu_{0} \omega\left[\begin{array}{l}
G_{x \eta}^{E}\left(\omega, \mathbf{r}, \mathbf{r}_{s}\right) J_{\eta}^{s}\left(\omega, \mathbf{r}_{s}\right) \\
G_{y \eta}^{E}\left(\omega, \mathbf{r}, \mathbf{r}_{s}\right) J_{\eta}^{s}\left(\omega, \mathbf{r}_{s}\right) \\
G_{z \eta}^{E}\left(\omega, \mathbf{r}, \mathbf{r}_{s}\right) J_{\eta}^{s}\left(\omega, \mathbf{r}_{s}\right)
\end{array}\right] \Delta V
$$

と表される . 同樣に磁場に対しても

$$
\mathbf{H}_{\eta}^{\prime}\left(\omega, \mathbf{r}, \mathbf{r}_{s}\right)=\left[\begin{array}{l}
H_{x \eta}^{\prime}\left(\omega, \mathbf{r}, \mathbf{r}_{s}\right) \\
H_{y \eta}^{\prime}\left(\omega, \mathbf{r}, \mathbf{r}_{s}\right) \\
H_{z \eta}^{\prime}\left(\omega, \mathbf{r}, \mathbf{r}_{s}\right)
\end{array}\right]=\left[\begin{array}{l}
G_{x \eta}^{H}\left(\omega, \mathbf{r}, \mathbf{r}_{s}\right) J_{\eta}^{s}\left(\omega, \mathbf{r}_{s}\right) \\
G_{y \eta}^{H}\left(\omega, \mathbf{r}, \mathbf{r}_{s}\right) J_{\eta}^{s}\left(\omega, \mathbf{r}_{s}\right) \\
G_{z \eta}^{H}\left(\omega, \mathbf{r}, \mathbf{r}_{s}\right) J_{\eta}^{s}\left(\omega, \mathbf{r}_{s}\right)
\end{array}\right] \Delta V
$$

と表される .式中，電磁場の下付き文字は 1 文字目が電場の方向を，2文字目が摇動電流の方向を表す .これら式

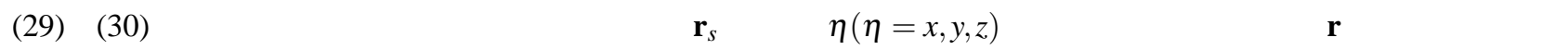
であり，電磁波解析によって求められる．ここで摇動電流がつくる，規格化されたポインティングベクトルは，

$$
\mathbf{s}_{\eta}\left(\omega, \mathbf{r}, \mathbf{r}_{s}\right)=\left[\begin{array}{l}
H_{z \eta}^{*} E_{y \eta}-H_{y \eta}^{*} E_{z \eta} \\
H_{x \eta}^{*} E_{z \eta}-H_{z \eta}^{*} E_{x \eta} \\
H_{y \eta}^{*} E_{x \eta}-H_{x \eta}^{*} E_{y \eta}
\end{array}\right]=\frac{1}{\left|J_{\eta}^{s}\left(\omega, \mathbf{r}_{s}\right)\right|^{2}}\left[\begin{array}{l}
H_{z \eta}^{\prime *} E_{y \eta}^{\prime}-H_{y \eta}^{\prime *} E_{z \eta}^{\prime} \\
H_{x \eta}^{\prime *} E_{z \eta}^{\prime}-H_{z \eta}^{\prime *} E_{x \eta}^{\prime} \\
H_{y \eta}^{\prime *} E_{x \eta}^{\prime}-H_{x \eta}^{\prime *} E_{y \eta}^{\prime}
\end{array}\right]=i \mu_{0} \omega(\Delta V)^{2}\left[\begin{array}{l}
G_{z \eta}^{H *} G_{y \eta}^{E}-G_{y \eta}^{H *} G_{z \eta}^{E} \\
G_{x \eta}^{H *} G_{z \eta}^{E}-G_{z \eta}^{H *} G_{x \eta}^{E} \\
G_{y \eta}^{H *} G_{x \eta}^{E}-G_{x \eta}^{H *} G_{y \eta}^{E}
\end{array}\right],
$$

である .この関係式を用いて , 式 (4) は摇動電流の位置 $\mathbf{r}_{s}$ につて以下のように離散化される .

$$
\langle\mathbf{S}(\omega, \mathbf{r})\rangle=2 \frac{\varepsilon_{0} \omega}{\pi} \varepsilon_{r}^{\prime \prime}(\omega) \Theta(\omega, T) \operatorname{Re}\left\{\frac{1}{\Delta V} \sum_{i_{s}, j_{s}, k_{s}}\left[\begin{array}{l}
\left(H_{z x}^{*} E_{y x}-H_{y x}^{*} E_{z x}\right)+\left(H_{z y}^{*} E_{y y}-H_{y y}^{*} E_{z y}\right)+\left(H_{z z}^{*} E_{y z}-H_{y z}^{*} E_{z z}\right) \\
\left(H_{x x}^{*} E_{z x}-H_{z x}^{*} E_{x x}\right)+\left(H_{x y}^{*} E_{z y}-H_{z y}^{*} E_{x y}\right)+\left(H_{x z}^{*} E_{z z}-H_{z z}^{*} E_{x z}\right) \\
\left(H_{y x}^{*} E_{x x}-H_{x x}^{*} E_{y x}\right)+\left(H_{y y}^{*} E_{x y}-H_{x y}^{*} E_{y y}\right)+\left(H_{y z}^{*} E_{x z}-H_{x z}^{*} E_{y z}\right)
\end{array}\right]\right\} .
$$

ここで電流密度の位置 $\mathbf{r}_{s}$ は , $\mathbf{r}_{s}=\left(i_{s} \Delta x, j_{s} \Delta y, k_{s} \Delta z\right)$ である . また式 (32) は, 単位強度摇動電流がつくるポインティ ングベクトルを用いて

$$
\langle\mathbf{S}(\omega, \mathbf{r})\rangle=2 \frac{\varepsilon_{0} \omega}{\pi} \varepsilon_{r}^{\prime \prime}(\omega) \Theta(\omega, T) \operatorname{Re}\left\{\frac{1}{\Delta V} \sum_{i_{s}, j_{s}, k_{s}}\left[\mathbf{s}_{x}+\mathbf{s}_{y}+\mathbf{s}_{z}\right]\right\} .
$$

と表される．したがってふく射輸送量は, 放射体内部の各点 $\mathbf{r}_{s}$ について, 観測点 $\mathbf{r}$ に単位強度摇動電流がつくる ポインティングベクトルを電磁場解析によって求め, 式 (5)に代入することによって求められる .

\section{Appendix}

C

複数の放射源（位置 $r_{j}$ ) が空気中の観測点 $r$ に作る周波数 $\omega$ の電磁場は以下のように表される .

$$
E(r, \omega)=\sum_{j} E\left(r, r_{j}, \omega\right)=\sum_{j} E_{j}^{0} \exp \left[i\left(\omega t+\phi_{j}\right)\right], \quad H(r, \omega)=\sum_{j} H_{j}^{0} \exp \left[i\left(\omega t+\phi_{j}\right)\right]
$$

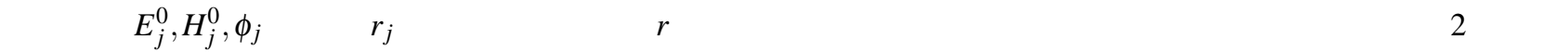
定すると，観測点につくるポインティングベクトルは，

$$
S(r, \omega)=H^{*}(r, \omega) E(r, \omega)=H_{1}^{0 *} E_{1}^{0}+H_{2}^{0 *} E_{2}^{0}+H_{1}^{0 *} E_{2} \exp \left[i\left(\phi_{2}-\phi_{1}\right)\right]+H_{2}^{0 *} E_{1} \exp \left[i\left(\phi_{1}-\phi_{2}\right)\right]
$$

と求められる.上式の右辺は光れ艺れ，第 1 項が放射源 1 のみの寄与，第 2 項が放射源 2 のみの寄与，第 3,4 項 が放射源 1 と 2 の干渉による寄与を表す .ここで，ふく射の放射という光の速度オーダーの現象を，実験などの ように相対的に長時間観測した場合，観測点では，2つの放射源による，あらゆる位相差の影響を受けるため，第 3, 4 項の干渉項は相殺される . 
次に , 放射源の大きさのモデル化が必要となる .これは放射体内部の電磁気学的応答をどの程度小さいスケー ルで考えられるかを意味する . 放射源の理想的な極限として，物体内部の点て誘電率を定義できるというモデル が式 (4)中の位置に関するディラックのデルタ関数で表されている .このときポインティングベクトルの時間平均 值は式 (5) で示されるように各微小体積要素内の摇動電流がつくるポインティングベクトルの和として表される .

\section{文献}

(1) Gombert, A., "An Overview of TPV Emitter Technologies", Proceedings of 5th Conference on Thermophotovoltaic Generation of Electricity, (2003), pp. 123-131.

(2) 牧野俊郎，若林英信, “薄膜系により放射される熱うく射球面波の干渉”，日本機械学会論文集 B 編，Vol. 72, No. 721 (2006), pp. 2256-2264.

(3) Hesketh, P.J., Zemel, J.N., and Gebhart, B., "Polarized spectral emittance from periodic micromachined surfaces. I. Doped silicon: The normal direction", Physical Review B, Vol. 37, No. 18 (1988), pp. 10795-10802 .

(4) Hesketh, P.J., Zemel, J.N., and Gebhart, B., "Polarized spectral emittance from periodic micromachined surfaces. II. Doped silicon: Angular variation", Physical Review B, Vol. 37, No. 18 (1988), pp. 10803-10813.

(5) Greffet, J.-J., Carminati, R., Joulain, K., Mulet, J.-P., Mainguy, S., and Chen, Y., "Coherent emission of light by thermal sources”, Nature, Vol. 416 (2002), pp. 61-64.

(6) Maruyama, S., Kashiwa, T., Yugami, H., and Esashi, M., "Thermal radiation from two-dimensionally confined modes in microcavities”, Applied Physics Letters, Vol. 79, No. 9 (2001), pp. 1393-1395.

(7) Lin, S.Y., Moreno, J., and Fleming, J.G., “Three-dimensional photonic-crystal emitter for thermal photovoltaic power generation”, Applied Physics Letters, Vol. 83, No. 2 (2003), pp. 380-382.

(8) Rytov, S.M., Kravtsov, Y.A., Tatarskii, V.I., "Principles of statistical radiophysics 3: elements of random fields", Berlin, Heidelberg, New York, Springer (1989).

(9) Francoeur, M., Mengüç, M.P., "Role of fluctuational electrodynamics in near-field radiative heat transfer", Journal of Quantitative Spectroscopy and Radiative Transfer, Vol. 109 (2008), pp. 280-293.

(10) Yee, K. S., "Numerical Solution of Initial Boundary Value Problems Involving Maxwell's Equations in Isotropic Media", IEEE Transactions on Antennas and Propagation, Vol. 14, No. 3 (1966), pp. 302-307.

(11) Kelley, D.F., and Luebbers, R.J., "Piecewise Linear Recursive Convolution for Dispersive Media Using FDTD", IEEE Transactions on Antennas and Propagation, Vol. 44, No. 6 (1996), pp. 792-797.

(12) Berenger, J.P., “A Perfectly Matched Layer for the Absorption of Electromagnetic Waves”, Journal of Computational Physics, Vol. 114 (1994), pp. 185-200.

(13) Correia D., "On the development of a higher-order PML”, IEEE Transactions on Antennas and Propagation, Vol. 53, No. 12 (2005), pp. 4157-4163.

(14) Luebbers, R. J., Kunz, K. S., Schneider M., and Hunsberger, F., "A Finite-Difference Time-Domain Near Zone to Far Zone Transformation", IEEE Transactions on Antennas and Propagation, Vol. 39, No. 4 (1991), pp. 429-433.

(15) Makino, T., "Present research on thermal radiation properties and characteristics of materials", International Journal of Thermophysics, Vol. 11, No. 2 (1990), pp. 339-352.

(16) 牧野俊郎, 阪井一郎, 木下博文, 国友孟, “セラミックスの熱うく射性質の研究”, 日本機械学会論文集 B 編, Vol. 50, No. 452 (1984), pp. 1045-1053.

(17) Chao, C.C., Tu, S.H. Wang, C.M., Huang, H.I., Chen, C.C, and Chang, J.Y., "Impedance-Matching Surface Plasmon Absorber for FDTD Simulations", Plasmonics, Vol. 5 (2010), pp. 51-55.

(18) Sipe, J.E., "New Green-function formalism for surface optics", Journal of the Optical Society of America B, Vol. 4, No. 4 (1987), pp. 481-489. 